\title{
ALCOHOLIC VS. NON-ALCOHOLIC CHRONIC PANCREATITIS: SURGEONS' PERSPECTIVE FROM A TERTIARY CENTRE IN INDIA
}

\author{
Perspectiva dos cirurgiões sobre pancreatite crônica alcoólica vs. não-alcoólica de um centro terciário na Índia
}

Koustav JANA ${ }^{1}$, Sukanta RAY ${ }^{1 \oplus}$, Roby DAS ${ }^{1 \oplus}$, Dilip KUMAR $^{1 \oplus}$, Tuhin S MANDAL $^{1 \oplus}$, Somak DAS ${ }^{1 \oplus}$

ABSTRACT - Background: Although alcohol is the most common cause for chronic pancreatitis worldwide, idiopathic type is prevalent in India. Natural history and disease progression are different between these two groups. There is paucity of data comparing surgical outcome and quality of life in these patients. Aim: To evaluate clinical features, surgical outcome and quality of life between these two groups of patients. Method: All patients with chronic pancreatitis who underwent surgery were prospectively reviewed. Results: From 98 patients, 42 were alcoholic. Number of male and the mean age at the time of operation was significantly more in alcoholic patients. Smoking, preoperative hospital admission rate and the prevalence of local complications like inflammatory pancreatic head mass, biliary stricture and left sided portal hypertension were distinctly more common in alcoholic group. Frey procedure was required more commonly in alcoholic group. Mean postoperative hospital stay and overall postoperative complication rate were comparable between the two groups. Over a median follow up of 18 months there was significant improvement in quality of life and pain score in both the groups. Improvement of physical functioning score at follow-up was significantly more in alcoholic group but the requirement for analgesic medications were significantly more in alcoholic group. However, appetite loss was more perceived by non-alcoholic group. Conclusion: Alcoholic chronic pancreatitis presents with more local complications associated with chronic pancreatitis. Frey procedure is a safe and well accepted surgery in this group. Though they required more analgesic requirement in short term follow up, other aspects of quality of life are similar to non-alcoholic group.

HEADINGS: Chronic pancreatitis. Alcoholic. Frey procedure. Quality of life.

Central message
Local complications from chronic pancreatitis are
more frequent in alcoholic patients and resectional
surgery is more commonly performed procedure in
this group.

\begin{tabular}{|l|}
\hline Perspective \\
\hline Natural history and disease progression are different \\
in alcoholic and non-alcoholic chronic pancreatitis. \\
In this study we have found that local complications \\
like benign pancreatic head mass, biliary stricture are \\
significantly more common in alcoholic group. As \\
a result, resectional surgery and associated surgery \\
are more commonly performed in these patients. \\
Though immediate surgical outcome is similar in \\
both groups, alcoholic chronic pancreatitis patients \\
require more analgesic medications in intermediate- \\
term follow up. Again, they experienced more \\
improvement in physical functioning compared to \\
non-alcoholic patients during follow up.
\end{tabular}

RESUMO - Racional: Embora o álcool seja a causa mais comum de pancreatite crônica em todo o mundo, a forma idiopática é prevalente na Índia. A história natural e a progressão da doença são diferentes entre esses dois grupos. Há escassez de dados comparando o resultado cirúrgico e a qualidade de vida entre eles.Objetivo: Avaliar as características clínicas, o resultado cirúrgico e a qualidade de vida entre esses dois grupos de pacientes. Método: Todos os pacientes com pancreatite crônica operados foram revisados retrospectivamente. Resultados: Do total de 98 pacientes, 42 eram alcoolistas. O número de homens e a idade média no momento da operação foi significativamente maior nos alcoolistas. Tabagismo, taxa de internação pré-operatória e prevalência de complicações locais como massa inflamatória da cabeça do pâncreas, estenose biliar e hipertensão portal do lado esquerdo foram distintamente mais comuns no grupo de alcoolistas e o procedimento de Frey foi exigido mais comumente neste grupo. A média de internação pós-operatória e a taxa geral de complicações pós-operatórias foram comparáveis entre os dois grupos. Ao longo de acompanhamento médio de 18 meses houve melhora significativa na qualidade de vida e pontuação de dor em ambos os grupos. A melhora no escore de funcionamento físico foi significativamente maior no grupo de alcoolistas, mas a necessidade de medicamentos analgésicos foi significativamente maior nos alcoolistas. No entanto, a perda de apetite foi mais percebida pelo grupo não alcoólico. Conclusão: A pancreatite crônica alcoólica se apresenta com mais complicações locais associadas à pancreatite crônica. O procedimento de Frey é operação segura e bem aceita neste grupo. Embora exigissem mais necessidade de analgésicos no acompanhamento em curto prazo, outros aspectos da qualidade de vida são semelhantes ao grupo não alcoólico.

DESCRITORES: Pancreatite crônica. Alcoolismo. Procedimento de Frey. Qualidade de vida.

Correspondence:

Koustav Jana

E-mail: koustavbsmc@gmail.com
Financial source: none.

Conflict of interest: none

Received for publication: 25/11/2020

Accepted for publication: 04/03/2021 
INTRODUCTION

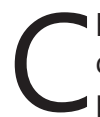
hronic pancreatitis (CP) is a progressive inflammatory disease leading to irreversible damage of the pancreas. The most common etiology in West is chronic alcohol intake whereas idiopathic pancreatitis (or tropical pancreatitis) is reported to be most common etiology in India and China, accounting for approximately $70 \%$ of all patients ${ }^{13}$. Recent few papers have suggested alcoholism as a dominant cause of it in India ${ }^{15,22}$. Though genetic study and clinical features have suggested that tropical pancreatitis is different from idiopathic chronic pancreatitis ${ }^{12}$, one thing is common in both idiopathic and tropical pancreatitis: absence of alcohol intake. Natural history of alcoholic pancreatitis is different from non-alcoholic ${ }^{2}$. One recent study has shown the different genetic pattern for alcoholic chronic pancreatitis than other chronic pancreatitis ${ }^{28}$. In this part of India where genetic analysis is not prevalent widely, etiology of CP can be broadly classified as alcoholic and nonalcoholic.

Pain is the most distressing symptom and most of the patients seek medical advice for disabling pain. Since chronic pancreatitis is a benign non-curable disease with a protracted natural course, pain relief as the successful outcome of the disease reflects only one aspect of the multidimensional outcome. As result, health-related quality of life as subjectively perceived by the patient, is becoming a major issue in the evaluation of any therapeutic intervention, mainly in patients with chronic diseases. In the current step-up approach, surgery is regarded as a last resort when other modalities fail. Several studies ${ }^{3,4,17,18,24,25}$ have shown that surgery for CP leads to pain relief and substantial improvement of health related quality of life in long-term follow up. Most these studies evaluate the nature of surgery and their long-term effect on the course of the disease. However, the quality of life in any alcoholics is quite different from healthy individuals or even from non-alcoholic patients. Several psychological and social factors interplay to determine the quality of life in alcohol dependents ${ }^{23}$. As earlier stated the natural history of alcoholic chronic pancreatitis is different from non-alcoholic ${ }^{2}$, treatment modalities and outcome may differ in long-term follow up.

The aim of this study was to evaluate clinical features, surgical outcome and quality of life after surgery in alcoholic and nonalcoholic chronic pancreatitis.

\section{METHODS}

This prospective observational analysis was performed in the Department of Surgical Gastroenterology, School of Digestive and Liver Diseases, Seth Sukhlal Karnani Memorial Hospital and the Institute of Post-Graduate Medical Education\&Research, Kolkata, India. Between October 2016 and October 2019 all patients who underwent surgery for chronic pancreatitis were included. Patients diagnosed with malignant disease, h/o acute illness within four weeks and inability to understand the questionnaire were excluded from the study. All patients had a detailed history and clinical examination. The diagnosis of chronic pancreatitis was based on typical history of abdominal pain and pancreatic parenchymal/ductal calcification and/or dilatation of the main pancreatic duct on imaging. Alcoholic $\mathrm{CP}$ was diagnosed in presence of daily alcohol intake of $>80$ $\mathrm{g} /$ day alcohol for at least five years ${ }^{1}$. Other investigations included complete hemogram, liver function test, and renal function test. Upper gastrointestinal endoscopy was suggested in suspicion of portal hypertension.

\section{Operative procedures}

Decision and type of surgery were finalised aftermultidisciplinary meeting between gastroenterologist, radiologist and primary surgeon. Only pancreatic ductal drainage (longitudinal pancreaticojejunostomy - LPJ) was performed in presence of dilated duct caused by stricture or stone, without an inflammatory head mass. A jejunal Roux loop was anastomosed side to side to whole length of pancreas from tail to head in single layer of continuous suture (3-0 or 4-0 polypropylene). We kept the length of the Roux limb around $60 \mathrm{~cm}$ as it could be used later for biliary bypass if the patient develops biliary stricture in future. Drainage procedure combined with a local resection as described by Frey and Smith ${ }^{11}$ was performed in presence of an inflammatory large head mass ( $>4 \mathrm{~cm}$ or more). However, simultaneous bilioenteric bypass was performed with the same loop in presence of obstructive jaundice or common bile duct stent. Izbicki procedure was performed in small duct disease (MPD diameter $\leq 3 \mathrm{~mm}$ ) as described by Izbicki and colleagues ${ }^{18}$. Reconstruction was similar to LPJ. Pancreaticoduodenectomy was performed only in case of severe duodenal obstruction or malignancy could not be ruled out preoperatively. Distal pancreatectomy with or without splenectomy was performed in case of extensive disease at distal body or tail region. However, patients who were found to have malignancy after histopathological examination were excluded from the study.

\section{Data collection and follow up}

Clinicopathological and operative data were collected from our prospectively maintained database. Postoperative complications were assessed according to Clavien-Dindo classification ${ }^{8}$ and postoperative mortality was defined as death within 90 days after the operation. Postoperative pancreatic fistulas, delayed gastric emptying and postoperative haemorrhage were diagnosed and classified based on International Study Group of Pancreatic Surgery criteria ${ }^{6,26,27}$. The patients were followed in the outpatient department. Follow up protocol in our department is every three months for the first two years, then six monthly for next three years, then annually for rest of the life. In the follow up, following parameters were recorded: body weight, pain, analgesic requirement, need for enzyme supplementation, need for hospitalization and blood sugar (both fasting and postprandial). Diabetes mellitus or endocrine insufficiency was defined if fasting blood sugar was more than $126 \mathrm{mg} / \mathrm{dl}$ and serum glycosylated hemoglobin was more than $6.5 \%$. Pancreatic exocrine insufficiency was considered in presence of steatorrhoea and or the need to take pancreatic enzyme supplementation. Fecal elastase estimation was not available in our institution to assess pancreatic exocrine function.

\section{Quality of life assessment and pain score}

The quality of life was assessed by the Bengali and Hindi version of European Organization for Research and Treatment of Cancer Quality of Life Questionnaire (EORTC QLQ C-30) ${ }^{10}$. It consists of five functional scales, three symptom scales, a global health status/QoL scale, and six single items. Different set of questions are included in the multi-item scale. All scales and single-item measures range in score from 0 to 100 . A high score in any functional scale denotes a high/healthy level of functioning, but a high score for a symptom scale/ item represents a high level of symptomatology/problems. Functional scales include physical functioning, role functioning, emotional functioning, cognitive functioning, and social functioning. Symptoms scales/items include fatigue, nausea and vomiting, pain, dyspnoea (DY), insomnia, appetite loss, constipation, diarrhoea and financial difficulties. Experience of pain from this debilitating disease was evaluated by the validated Izbicki pain score ${ }^{9}$ having the following components: frequency of pain attacks, a visual analog scale of pain, analgesic medication used, and inability to work. All participants were requested to fill up the EORTC QLQ C30 questionnaire and 
Izbicki pain score in the hospital before surgery and during each follow up visit.

\section{Statistical analysis}

All the categorical variables were expressed as percentage and the continuous variables were expressed as mean+/-SD as well as median and range value. Comparisons of various domains of QOL and pain scores before and after surgery were performed using 'paired t test'. Comparison of various domains of QOL and pain scores between alcoholic and non-alcoholic were performed by using 'individual sample t test'. $p \leq 0.05$ was regarded as significant. All calculations were performed with IBM SPSS software, version 26.0.

RESULTS

One hundred and six patients with CP underwent surgery during the study period. Eight were excluded as five were below 15 years, two had malignancy in final biopsy and one acute illness within four weeks. Thus, 98 patients were included in the present study. Of these, alcohol was aetiology in 42 cases and overall 63 were male (64.3\%). In the alcoholic group male:female was 41:1 and it was 22:34 in non-alcoholic group $(p=0.00)$. Mean age at the time of surgery was 34.15 years and it was 39.62 and 30.05 years in alcoholic and non-alcoholic group respectively $(p=0.00)$. There was more smoker in alcoholic group (18 vs. $6, p=0.00)$. Alcoholic CP also experienced frequent preoperative hospital admission due to abdominal pain (18.14 vs. 9.20, $p=0.05$ ). Pancreatic head mass and biliary stricture were distinctly predominant in alcoholic group ( 18 vs. $4, p=0.00$ and 10 vs. $4, p=0.03$, respectively). Others demographic and preoperative clinical data in alcoholic and non-alcoholic group are presented in Table 1.

\section{Operative data}

Operative procedures and data are summarized in Table 2.

The most frequent surgical procedure was Frey procedure (46.9\%), closely followed by lateral pancreaticojejunostomy (43.9\%). However, Frey procedure was more common in alcoholic group (28 vs. 18 ) whereas LPJ was distinctly more common in non-alcoholic (35 vs. 8). Most common additional procedure was cholecystectomy. Mean operative time was $248.54 \mathrm{~min}(+/-43.08)$ and mean blood loss was $161.73 \mathrm{ml}$ (+/-121.79). There was no difference in operative time and intraoperative blood loss in alcoholic and non-alcoholic

TABLE 1 - Demographic and preoperative clinical data

\begin{tabular}{|c|c|c|c|c|}
\hline & $\begin{array}{c}\text { Overall } \\
(n=98) \\
(\text { mean }+/-s d)\end{array}$ & $\begin{array}{c}\text { Alcoholic } \\
(n=42) \\
(\text { mean+/- sd) }\end{array}$ & $\begin{array}{l}\text { Non-alcoholic } \\
\qquad(n=56) \\
(\text { mean }+/-s d)\end{array}$ & $p$ \\
\hline Age (in years) & $34.15+/-11.25$ & $39.62+/-10.27$ & $30.05+/-10.22$ & 0.00 \\
\hline Gender (M:F) & 63:35 & $41: 1$ & $22: 34$ & 0.00 \\
\hline Weight (in kg) & $50.43+/-8.47$ & $51.03+/-8.45$ & $49.98+/-8.53$ & 0.54 \\
\hline Duration of pain (in months) & $59.9+/-59.21$ & $54.19+/-64.33$ & $64.18+/-55.28$ & 0.41 \\
\hline Number of prior hospitalization & $13.03+/-22.89$ & $18.14+/-28.62$ & $9.20+/-\quad 16.68$ & 0.05 \\
\hline Prior surgery/endoscopic therapy & 15 & 4 & 11 & 0.25 \\
\hline Smoker & $24(24.5 \%)$ & 18 & 6 & 0.00 \\
\hline Endocrine insufficiency & $30(30.6 \%)$ & 11 & 19 & 0.50 \\
\hline Exocrine insufficiency & $6(6.1 \%)$ & 3 & 3 & 1.00 \\
\hline Preoperative albumin & $3.88+/-0.61$ & $3.76+/-$ & $3.96+/-0.60$ & 0.10 \\
\hline Preoperative hemoglobin & $11.60+/-1.84$ & $11.92+/-2.05$ & $11.35+/-1.65$ & 0.12 \\
\hline Preoperative bilirubin & $0.73+/-0.43$ & $0.69+/-0.23$ & $0.77+/-0.53$ & 0.39 \\
\hline Preoperative ALP & $201.92+/-156.15$ & $229.45+/-177.96$ & $181.27+/-135.58$ & 0.13 \\
\hline Head of pancreas mass & $22(22.4)$ & 18 & 4 & 0.00 \\
\hline Biliary stricture & $14(14.3)$ & 10 & 4 & 0.03 \\
\hline Gall stone & 1 & 0 & 1 & 1.00 \\
\hline Pseudocyst & 2 & 1 & 1 & 1.00 \\
\hline Splenic vein thrombosis & 2 & 1 & 1 & 1.00 \\
\hline Pseudoaneurysm & 2 & 1 & 1 & 1.00 \\
\hline MPD diameter & $7.12+/-2.95$ & $6.47+/-2.52$ & $7.51+/-3.26$ & 0.09 \\
\hline
\end{tabular}

TABLE 2 - Operative procedures and data

\begin{tabular}{|c|c|c|c|c|}
\hline & Overall & Alcoholic & Non-alcoholic & $p$ \\
\hline \multicolumn{5}{|l|}{ Type of surgery } \\
\hline Frey & 46(46.9) & 28 & 18 & \multirow{5}{*}{0.00} \\
\hline LPJ & $43(43.9)$ & 8 & 35 & \\
\hline Distal pancreatectomy & $5(5.1)$ & 3 & 2 & \\
\hline Izbicki procedure & $3(3.1)$ & 2 & 1 & \\
\hline Pancreaticogastrostomy & $1(1.0)$ & 1 & 0 & \\
\hline \multicolumn{5}{|l|}{ Associated surgery } \\
\hline Cholecystectomy & $9(9.1)$ & 5 & 4 & \multirow{5}{*}{0.14} \\
\hline Choledochojejunostomy & $6(6.1)$ & 4 & 2 & \\
\hline Hepaticojejunostomy & $5(5.1)$ & 3 & 2 & \\
\hline Reinsertion of CBD in cavity & $5(5.1)$ & 4 & 1 & \\
\hline Cystojejunostomy & $3(3.1)$ & 2 & 1 & \\
\hline Blood loss & $161.73+/-121.79$ & $160.71+/-109.62$ & $162.50+/-131.16$ & 0.94 \\
\hline Duration of surgery & $248.54+/-43.08$ & $255.52+/-41.788$ & $243.30+/-43.676$ & 0.16 \\
\hline Left sided portal hypertension & $21(21.4)$ & 14 & 7 & 0.02 \\
\hline Tissue removed in Frey & $9.33+/-5.36$ & $10.12+/-6.26$ & $8.11+/-3.34$ & 0.21 \\
\hline
\end{tabular}


groups ( $p=0.16$ and 0.94 respectively). Left sided portal hypertension was found in 21 patients $(21.6 \%)$ and it was significantly higher in alcoholic group (14 vs. $7, p=0.02$ ). Mean weight of tissue removed by pancreatic head coring in Frey procedure was $9.33 \mathrm{~g} \mathrm{(+/-5.36)}$ and it was 10.12(+/6.26) $\mathrm{g}$ and $8.11(+/-3.34) \mathrm{g}$ in alcoholic and non-alcoholic groups, respectively $(p=0.21)$.

\section{Postoperative data}

Mean hospital stay was 9.41 days (+/-2.96). Fifty postoperative complications developed in total 39 patients (39.79\%). Among them, 21 were non-alcoholic and 18 were alcoholic CP (37.5\% vs. $42.85 \%, p=0.67)$. Twelve major complications (Clavien Dindo 3 or above) developed in 10 patients. There was no postoperative mortality in the present study (Table 3).

TABLE 3 - Postoperative complications $(n=39)$

\begin{tabular}{|c|c|c|}
\hline $\begin{array}{l}\text { Complication } \\
\text { Grade }\end{array}$ & $\begin{array}{l}\text { Complications } \\
\qquad(n=50)\end{array}$ & Details \\
\hline I & 16 & $\begin{array}{l}\text { Mild wound infection managed in the ward } n=10 \\
\text { Biochemical leak (Gr A PF) no intervention } n=6\end{array}$ \\
\hline II & 22 & $\begin{array}{l}\text { Biochemical leak (Gr A PF) requiring discharge } \\
\text { with abdominal drain and removed within three } \\
\text { weeks, } n=9 \\
\text { Post-pancreatectomy haemorrhage requiring } \\
\text { blood transfusion, } n=3 \\
\text { Chest infection treated with antibiotics and chest } \\
\text { physiotherapy, } n=2 \\
\text { Delayed gastric emptying (Gr A), managed with } \\
\text { prokinetics, } n=3 \\
\text { Chyle leak, treated with parenteral nutrition and } \\
\text { medium chain triglyceride, } n=1 \\
\text { Seizures, controlled with antiepileptic drugs, } n=1 \\
\text { Ascites, managed withIValbumin and diuretics, } n=1 \\
\text { Hypoglycaemia, } n=1 \\
\text { Transfusion reaction, } n=1\end{array}$ \\
\hline IIla & 6 & $\begin{array}{l}\text { Severe wound infection requiring secondary } \\
\text { suturing, } n=3 \\
\text { Grade } B P F, n=3 \text { (In two patients percutaneous } \\
\text { drain were placed and, in another patient, drain } \\
\text { repositioning done) }\end{array}$ \\
\hline IIIb & 4 & $\begin{array}{l}\text { Complete wound dehiscence (burst abdomen), } \\
\text { requiring secondary suturing under general } \\
\text { anaesthesia, } n=1 \\
\text { Re-exploration due to post-pancreatectomy } \\
\text { haemorrhage }(\mathrm{Gr} B / C), n=3\end{array}$ \\
\hline IVa & 2 & $\begin{array}{l}\text { Re-exploration due to } \mathrm{PPH} \text { with single organ } \\
\text { dysfunction, } n=2 \text { (one developed non-arteriticoptic } \\
\text { neuritis and other developed acute renal failure) }\end{array}$ \\
\hline $\mathrm{IVb}$ & 0 & No multiorgan dysfunction in the study group \\
\hline V & 0 & No postoperative death in the study group \\
\hline
\end{tabular}

Most common postoperative complication was pancreatic leak $(n=18)$. Fifteen patients had biochemical leak that was managed conservatively. Three had grade B postoperative pancreatic fistula. One had persistent drainage beyond three weeks and required repositioning of the drain. Another two developed abdominal collection for which ultrasound guided percutaneous drain was placed. Postoperative pancreatic haemorrhage occurred in eight patients. Among these, Frey procedure was performed in seven and Izbicki procedure in one. Three patients were managed conservatively and five needed re-exploration. The source of bleeding was cored out head cavity in all five. One patient of postoperative haemorrhage developed nonarteritic ischaemic optic neuritis due to severe hypotension. Hospital stay and specific complications were compared, and no difference was found between alcoholic and nonalcoholic groups (Table 4).
TABLE 4 - Postoperative data comparison

\begin{tabular}{|c|c|c|c|c|}
\hline & $\begin{array}{l}\text { Overall } \\
(n=98)\end{array}$ & $\begin{array}{l}\text { Alcoholic } \\
(n=42)\end{array}$ & $\begin{array}{l}\text { Non-alcoholic } \\
\qquad(n=56)\end{array}$ & $p$ \\
\hline $\begin{array}{l}\text { Hospital stay (in } \\
\text { days) }\end{array}$ & $9.41+/-2.96$ & $9.83+/-3.06$ & $9.09+/-2.87$ & 0.22 \\
\hline $\begin{array}{l}\text { Overall } \\
\text { complications (no } \\
\text { of patients) }\end{array}$ & 39(39.79\%) & 18(42.85\%) & $21(37.5 \%)$ & 0.67 \\
\hline POPF & \multicolumn{4}{|c|}{$18(18.36 \%)$} \\
\hline Grade A & 15 & 9 & 6 & \multirow{2}{*}{0.21} \\
\hline Grade B & 3 & 2 & 1 & \\
\hline $\mathrm{PPH}$ & \multicolumn{4}{|c|}{$8(8.16 \%)$} \\
\hline Grade A & 1 & 1 & 0 & \multirow{3}{*}{0.67} \\
\hline Grade B & 4 & 2 & 2 & \\
\hline Grade C & 3 & 1 & 2 & \\
\hline
\end{tabular}

$\mathrm{POPF}=$ Postoperative pancreatic fistula; $\mathrm{PPH}=$ postoperative pancreatic haemorrhage

\section{Follow-up data}

Median follow up was 18 months (6-30). During this period, new onset diabetes mellitus was documented in three patients (two of them underwent Frey procedure, other LPJ). At the end of follow up, 33 patients (33.67\%) were diabetic. Of them 23 were on insulin and 10 on oral hypoglycaemic agents. No patient developed new onset exocrine insufficiency and there was no improvement of preoperatively diagnosed exocrine insufficiency. Benign biliary stricture developed in two patients who underwent Frey procedure previously. Choledochojejunostomy was performed in both of them using the same loop that was used for pancreaticojejunostomy. One patient developed incisional hernia and prolene mesh repair was performed. Body weight was not found to be significantly improved after surgery in both the groups (Table 5).

TABLE 5 - Comparison of body weight

\begin{tabular}{|c|c|c|c|}
\hline Body weight & Preoperative & At follow up & $p$ \\
\hline Alcoholic & $51.036+/-8.45$ & $51.988+/-8.18$ & 0.269 \\
\hline Non-alcoholic & $49.982+/-8.53$ & $48.893+/-8.33$ & 0.234 \\
\hline Overall & $50.434+/-8.47$ & $50.219+/-8.36$ & 0.738 \\
\hline
\end{tabular}

\section{Quality of life and pain score assessment}

Overall quality of life and Izbicki pain score were significantly improved after surgery (Table 6 ) though 10 patients (10.2\%) had incomplete pain relief at their last follow up visit. Among them six were in alcoholic group and four in non-alcoholic.

TABLE 6 - QOL score and pain score before and after surgery

\begin{tabular}{|l|c|c|c|}
\hline \multicolumn{1}{|c}{ Parameters } & $\begin{array}{c}\text { Preoperative } \\
\text { Mean } \pm \text { SD }\end{array}$ & $\begin{array}{c}\text { At follow up } \\
\text { Mean } \pm \text { SD }\end{array}$ & $p$ \\
\hline Global heath score & $46.58 \pm 18.04$ & $74.31 \pm 14.44$ & 0.001 \\
\hline Physical functioning score & $67.21 \pm 18.84$ & $89.45 \pm 16.77$ & 0.001 \\
\hline Role functioning score & $62.92 \pm 29.26$ & $88.60 \pm 15.43$ & 0.001 \\
\hline Emotional functioning score & $60.79 \pm 21.67$ & $86.64 \pm 14.69$ & 0.001 \\
\hline Cognitive functioning score & $63.94 \pm 27.98$ & $86.56 \pm 18.48$ & 0.002 \\
\hline Social functioning score & $63.26 \pm 28.31$ & $85.20 \pm 18.67$ & 0.001 \\
\hline Fatigue score & $46.14 \pm 23.84$ & $14.51 \pm 17.93$ & 0.002 \\
\hline Nausea and vomiting score & $39.45 \pm 29.54$ & $12.58 \pm 14.76$ & 0.002 \\
\hline Pain score & $46.93 \pm 30.58$ & $16.83 \pm 19.80$ & 0.001 \\
\hline Dyspnoea score & $34.69 \pm 29.47$ & $9.52 \pm 17.91$ & 0.002 \\
\hline Insomnia score & $47.27 \pm 30.99$ & $17.00 \pm 23.56$ & 0.001 \\
\hline Appetite loss score & $45.91 \pm 30.08$ & $15.30 \pm 22.53$ & 0.002 \\
\hline Constipation score & $34.69 \pm 32.43$ & $13.94 \pm 21.89$ & 0.001 \\
\hline Diarrhoea score & $33.33 \pm 31.74$ & $12.58 \pm 18.85$ & 0.001 \\
\hline Financial difficulties score & $49.65 \pm 32.19$ & $13.26 \pm 22.82$ & 0.001 \\
\hline Pain score & & & \\
\hline Visual analogue score & $85.82 \pm 16.74$ & $12.35 \pm 22.64$ & 0.002 \\
\hline Frequency of attack & $71.68 \pm 24.51$ & $12.24 \pm 23.61$ & 0.001 \\
\hline Analgesic medications & $18.86 \pm 11.36$ & $2.35 \pm 5.73$ & 0.001 \\
\hline Inability to work & $50.00 \pm 21.23$ & $6.38 \pm 14.07$ & 0.001 \\
\hline Pain score & $56.58 \pm 12.12$ & $8.32 \pm 14.75$ & 0.001 \\
\hline
\end{tabular}


TABLE 7 - QOL score and pain score in alcoholic and non-alcoholic

\begin{tabular}{|c|c|c|c|c|c|c|}
\hline & \multicolumn{3}{|c|}{ Preoperative } & \multicolumn{3}{|c|}{ During follow up } \\
\hline & Alcoholic & Non-alcoholic & $\mathrm{p}$ & Alcoholic & Non-alcoholic & $\mathrm{p}$ \\
\hline \multicolumn{7}{|l|}{ QOL score } \\
\hline GH Score & $45.52 \pm 19.64$ & $47.80 \pm 16.92$ & 0.540 & $73.17 \pm 14.37$ & $75.14 \pm 14.56$ & 0.507 \\
\hline PF Score & $63.73 \pm 17.95$ & $69.7 \pm 19.23$ & 0.123 & $93.33 \pm 10.95$ & $86.67 \pm 19.55$ & 0.052 \\
\hline RF Score & $61.38 \pm 25.39$ & $64.03 \pm 31.93$ & 0.660 & $89.83 \pm 14.85$ & $87.71 \pm 15.91$ & 0.506 \\
\hline EF Score & $59.95 \pm 20.51$ & $61.40 \pm 22.63$ & 0.747 & $88.00 \pm 13.31$ & $85.67 \pm 15.65$ & 0.440 \\
\hline CF Score & $61.38 \pm 27.24$ & $65.78 \pm 28.59$ & 0.445 & $89.02 \pm 18.10$ & $84.79 \pm 18.70$ & 0.266 \\
\hline SF Score & $59.34 \pm 27.90$ & $66.08 \pm 28.51$ & 0.248 & $85.36 \pm 14.52$ & $85.08 \pm 21.28$ & 0.942 \\
\hline FA Score & $47.69 \pm 24.24$ & $45.02 \pm 23.7$ & 0.588 & $11.92 \pm 16.55$ & $16.37 \pm 18.79$ & 0.228 \\
\hline NV Score & $42.68 \pm 29.59$ & $37.13 \pm 29.54$ & 0.362 & $9.34 \pm 9.16$ & $14.91 \pm 17.44$ & 0.066 \\
\hline PA Score & $50.4 \pm 29.92$ & $44.44 \pm 31.07$ & 0.344 & $17.07 \pm 20.91$ & $16.66 \pm 19.15$ & 0.921 \\
\hline DY Score & $35.77 \pm 28.27$ & $33.91 \pm 30.53$ & 0.760 & $8.13 \pm 17.92$ & $10.52 \pm 17.99$ & 0.516 \\
\hline SL Score & $43.90 \pm 27.32$ & $49.70 \pm 33.40$ & 0.363 & $17.07 \pm 23.71$ & $16.95 \pm 23.67$ & 0.981 \\
\hline AP Score & $48.78 \pm 30.81$ & $43.85 \pm 29.65$ & 0.427 & $9.75 \pm 17.06$ & $19.29 \pm 25.15$ & 0.038 \\
\hline CO Score & $34.95 \pm 30.68$ & $34.5 \pm 33.9$ & 0.946 & $10.56 \pm 20.32$ & $16.37 \pm 22.81$ & 0.197 \\
\hline DI Score & $39.02 \pm 31.53$ & $29.23 \pm 31.54$ & 0.133 & $13.82 \pm 19.68$ & $11.69 \pm 18.35$ & 0.585 \\
\hline FI Score & $58.53 \pm 30.53$ & $43.27 \pm 32.09$ & 0.020 & $12.19 \pm 22.05$ & $14.03 \pm 23.52$ & 0.696 \\
\hline \multicolumn{7}{|l|}{ Pain score } \\
\hline Frequency of attack & $76.22 \pm 23.68$ & $68.42 \pm 24.78$ & 0.121 & $9.15 \pm 17.46$ & $14.47 \pm 27.11$ & 0.273 \\
\hline VAS & $86.34 \pm 16.24$ & $85.44 \pm 17.22$ & 0.794 & $11.46 \pm 22.42$ & $12.98 \pm 22.98$ & 0.75 \\
\hline Analgesic medications & $18.41 \pm 10.51$ & $19.18 \pm 12.02$ & 0.746 & $3.68 \pm 7.15$ & $1.39 \pm 4.26$ & 0.05 \\
\hline Inability to work & $52.44 \pm 20.77$ & $48.25 \pm 21.57$ & 0.338 & $7.32 \pm 15.04$ & $5.70 \pm 13.37$ & 0.577 \\
\hline Pain score & $58.35 \pm 11.75$ & $55.32 \pm 12.32$ & 0.224 & $7.90 \pm 14.30$ & $8.36 \pm 15.18$ & 0.810 \\
\hline
\end{tabular}

In 95 patients (96.9\%) there was improvement in all parameters of quality of life whereas in three improvement in global health score only. Other parameters of quality of life were not significantly improved in them. When we compared preoperative QOL and pain score between alcoholic and nonalcoholic group, we found financial difficulty to be significantly higher in alcoholic group $(p=0.020)$. During follow up period physical functioning was significantly improved in alcoholic group ( $p=0.05$ ) but appetite loss was more perceived in nonalcoholic group $(p=0.03)$. Requirement of analgesic medications was more in alcoholic group $(p=0.05$, Table 7$)$.

\section{DISCUSSION}

The term 'tropical pancreatitis' was coined by Zuidema et $\mathrm{al}^{30}$ to describe idiopathic chronic pancreatitis in developing countries. Recent review study by Garg PK ${ }^{12}$ had shown that tropical pancreatitis and idiopathic pancreatitis have distinct clinical course, different genetic pattern and different prognosis. However, idiopathic chronic pancreatitis (or tropical pancreatitis) is considered to be most common variety of chronic pancreatitis in India ${ }^{13}$. In our study we found alcoholic pancreatitis in $42.8 \%$ cases and non-alcoholic in $57.2 \%$. Though few cases of pancreas divisum were identified, in absence of genetic analysis we were unable to differentiate between idiopathic chronic pancreatitis and tropical chronic pancreatitis. As a result, non-alcoholic etiology remains the most common etiology in our study group. A research from South India ${ }^{22}$ indicates alcohol intake as a dominant emerging cause of CP and Halder SK et $\mathrm{al}^{15}$ had also mentioned alcohol as most common etiology in their study population.

Alcohol intake is not common for woman in Indian culture and as a result we found distinctly male predominant in alcoholic chronic pancreatitis. We also found significantly higher mean age in alcoholic group than non-alcoholic. This reflects several years of chronic alcoholism leads to CP and also idiopathic chronic pancreatitis and tropical chronic pancreatitis both occur in $2^{\text {nd }}$ and $3^{\text {rd }}$ decade ${ }^{12}$. Smoking is itself a risk factor for $\mathrm{CP}$, and also accelerates the progression of CP in alcoholics ${ }^{19,29}$. A nationwide study from India by
Balakrishnan et $\mathrm{al}^{5}$ had identified overall $28.3 \%$ smoker in CP patients and $59 \%$ of male alcoholics were smokers. In our data smoking was present in $42.8 \%(18 / 42)$ in alcoholic and only $10.7 \%(6 / 56)$ in non-alcoholic group. This may be explained by male predominance in alcoholic CP group and, also, heavy drinkers are often heavy smokers ${ }^{5,7}$.

Incidence of diabetes (overall 30.6\%) was similar to other reported Indian series ${ }^{5,20}$ but the incidence of exocrine insufficiency (overall 6.1\%) was lower compared to western series $^{14,21}$. The possible explanation may be less dietary fat intake by Indian population. During follow up period only three patients developed new onset diabetes and none new onset exocrine insufficiency. The low incidence of new diabetes and new exocrine insufficiency in our study may be due to very short duration of follow-up. Exocrine and endocrine function may deteriorate over time and needs long-term follow-up. However, we were unable to document improvement of body weight. This result can be attributed to very short-term follow up period.

Head of pancreas mass was preoperatively identified in 18 cases $(42.8 \%)$ in alcoholic group. Bordacahar et $\mathrm{al}^{7}$ had found significantly more local inflammation in posterior plane of the pancreas (53\% in alcoholic CP and $25 \%$ in controls, $p=0.05$ ). Biliary stricture was present in $14.3 \%$ in our study. Similar result was obtained by in a recent study by Hao et $\mathrm{al}^{16}$ where they found common bile duct stricture in $15.8 \%$ cases. They had included factors like male, age at onset, smoking, body mass index and morphology of main pancreatic duct to develop a nomogram to predict common bile duct stricture in chronic pancreatitis patients. The clinical profile of alcoholic chronic pancreatitis is also being reflected by nature of surgery performed. Frey procedure was more frequently performed in alcoholic group whereas LPJ was most commonly in non-alcoholic. Interestingly we performed total 46 Frey procedures whereas preoperatively we identified pancreatic head mass only in 22 cases. It may be explained by poor or inadequate preoperative computed tomography scan reporting and/or the mass was less than $<4 \mathrm{~cm}$ (not being enrolled as pancreatic head mass). This difference was reflected in amount of tissue removed in Frey procedure. Though it is not significantly different in two 
groups but in alcoholic group it was on higher side (10.12 vs. $8.11 \mathrm{~g}$ ). In study by Gestic et al ${ }^{14}$ median tissue removed in Frey was $14.8 \mathrm{~g}$ (7-78). In their work etiology of CP was alcohol abuse in $95.9 \%$ cases.

Several papers $3,4,25$ had compared Frey with Whipple or Beger procedures and was unable to find any significant difference in terms of pain relief, mortality and long-term morbidity. However, Frey procedure is technically easier and our preferred method. Again, in presence of extrahepatic/left sided portal hypertension the dissection of tunnel of Love beneath the neck of the pancreas, as required in Beger or Whipple procedures is likely to be tedious and risky ${ }^{21}$. In our study we found left sided portal hypertension in $21.4 \%$ cases and it was significantly higher in alcoholic group (14 vs. 7 $p=0.02$ ). Similar result was also obtained by Bordacahar et al $^{7}$. They found significantly more segmental portal hypertension in alcoholic CP in comparison to non-alcoholic CP (69\% vs. $31 \%, p=0.0069)$.

There was no perioperative mortality in our study and overall morbidity was present in $39.79 \%$ patients which is comparable with other studies ${ }^{14,20,21}$. Grade A pancreatic fistula or biochemical leak was most common complication in our study. Grade B occurred only in three. Hard texture of pancreatic parenchyma and decreased capacity of secretory function may explain this very low number of clinically relevant postoperative pancreatic fistula.

In our study the EORTC QLQ C-30 questionnaire and Izbicki pain score have been used to assess the quality of life and pain control. Both were well accepted by our patients and required around $22 \mathrm{~min}(15-40)$ to complete. There was significant improvement in all domains of QOL after surgery $(p<0.005)$ which was similar to that reported by various authors $4,17,18,24,25$. In our study, we found that financial difficulty was significantly higher in alcoholic patients before surgery which might be attributed to alcohol consumption itself. Again, it may reflect the different socioeconomic status in alcoholic patient ${ }^{9}$.

In our study we found $90 \%$ to have complete pain relief. Similar result have been reflected by various studies with very long-term follow up ${ }^{14,20,21}$. Factors like preoperative opiate use, continuous pattern of pain, long duration of pain $(>6 y)$, postoperative complications and age $\geq 38$ years were suggested for incomplete pain relief after surgery ${ }^{20}$ Bordacahar et al $^{7}$ had also suggested early surgery and preoperative complete smoking as favourable factor for improved quality of life after surgery in alcoholic CP.

During follow up physical functioning score was significantly improved after surgery in alcoholic group. Physical functioning score involved questions associated with physical work (e.g. any trouble during strenuous exercise or long walk, need to stay in bed during day, etc.). These questions may be not very appropriate for younger patients who are not very accustomed to this type of physical activity. This might be a reason for finding a better physical functioning score in alcoholic group where most of the patients are male and relatively higher age group. Interestingly analgesic requirement was higher in alcoholic group during follow up period. Again, it may reflect the narcotic abuse in alcoholic group.

However, there are several limitations on this research. First, this study was from a large, tertiary care referral centre. Therefore, it may reflect more severe disease than patients with chronic pancreatitis who are seen in primary care or community gastroenterology practice setting. Second, our median follow up period was only 18 months. Pain control and quality of life both may change in long-term follow up. Third, we have not analyzed the factors for incomplete pain relief in the follow up period.

\section{CONCLUSION}

Alcoholic chronic pancreatitis presents with more local complications than non-alcoholic chronic pancreatitis. Smoking is prevalent in this group and they experienced more hospital admission before surgery. Pancreatic head mass, benign biliary stricture and segmental or left sided portal hypertension are significantly more prominent in alcoholic group in compared to idiopathic or tropical pancreatitis. As a result, resectional surgery is more performed in alcoholic patients. Frey procedure is a safe and well accepted surgery with a very good short-term outcome. Though there is significant difference in some aspects of quality of life (physical functioning and appetite loss) and pain score (analgesics requirement), further long-term data needs to be evaluated for proper conclusion in these parameters.

\section{REFERENCES}

1. Ammann RW. A clinically based classification system for alcoholic chronic pancreatitis: summary of an international workshop on chronic pancreatitis. Pancreas. 1997 Apr 1;14(3):215-21.

2. Ammann RW, Buehler $H$, Muench $R$, Freiburghaus AW, Siegenthaler $W$. Differences in the natural history of idiopathic (nonalcoholic) and alcoholic chronic pancreatitis. A comparative long-term study of 287 patients. Pancreas. 1987 Jan 1:2(4):368-77.

3. BachmannK, TomkoetterL, ErbesJ,Hofmann B, Reeh M, PerezD, VashistY, Bockhorn M, IzbickiJR, MannO. Beger and Frey procedures for treatment of chronic pancreatitis: comparison of outcomes at 16-year follow-up. Journal of the American College of Surgeons. 2014 Aug 1;219(2):208-16.

4. Bachmann, K Tomkoetter, L Kutup, A Erbes, J Vashist, Y, Mann, O., Bockhorn, M. and Izbicki, J.R., 2013. Is the Whipple procedure harmful for long-term outcome in treatment of chronic pancreatitis? 15-years follow-up comparing the outcome after pylorus-preserving pancreatoduodenectomyandFreyprocedureinchronicpancreatitis.Annals of Surgery, 258(5), pp.815-821.

5. Balakrishnan V, Unnikrishnan AG, Thomas V, Choudhuri G, Veeraraju P, Singh SP, Garg P, Pai CG, Devi RN, Bhasin D, Jayanthi V. Chronic pancreatitis. A prospective nationwide study of 1,086 subjects from India. JOP: Journal of the pancreas. 2008 Sep 2;9(5):593-600.

6. Bassi C. International Study Group on Pancreatic Fistula Definition; Postoperative parcreatic fistula; an international study group (ISGPF) definition. Surgery. 2005;138:8-13.

7. BordaçaharB, CouvelardA, VulliermeMP, Bucchini L, SauvanetA, Dokmak S, Ruszniewski P, Lévy P, Rebours V. Predicting the efficacy of surgery for pain relief in patients with alcoholic chronic pancreatitis. Surgery. 2018 Nov 1;164(5):1064-70.

8. DindoD, Demartines N,ClavienPA.Classification of surgicalcomplications: a new proposal with evaluation in a cohort of 6336 patients and results of a survey. Annals of surgery. 2004 Aug;240(2):205.

9. Eashwar VA, Umadevi R, Gopalakrishnan S. Alcohol consumption in India-Anepidemiological review. Journal offamily medicine and primary care. 2020 Jan;9(1):49.

10. Fayers P, Bottomley AE, EORTC Quality of Life Group. Quality of life research within the EORTC - the EORTC QLQ-C30. European Journal of Cancer. 2002 Mar 1;38:125-33.

11. Frey CF, Smith GJ. Description and rationale of a new operation for chronic pancreatitis. Pancreas. 1987 Jan 1;2(6):701-7..

12. Garg PK. Chronic pancreatitis in India and Asia. Current gastroenterology reports. 2012 Apr;14(2):118-24.

13. GargPK, TandonRK.SurveyonchronicpancreatitisintheAsia-Pacificregion Journal of gastroenterology and hepatology. 2004 Sep;19(9):998-1004.

14. Gestic MA, Callejas-Neto F, Chaim EA, Utrini MP, Cazzo E, Pareja JC Surgical treatment of chronic pancreatitis using Frey's procedure: a Brazilian 16-yearsingle-centre experience.Hpb.2011 Apr 1;13(4):263-71.

15. Halder SK, BhattacharjeePK, BharP, Das C, Pandey P, RakshitKP, Pachaury A. AComparative Study Between Longitudinal Pancreacticojejunostomy v/s Lateral Pancreaticogastrostomy as a Drainage Procedure for Pain Relief in Chronic Pancreatitis Done in a Tertiary Referral Centre of Eastern India. Indian Journal of Surgery. 2015 Apr;77(2):120-4.

16. Hao L, Bi YW, Zhang D, Zeng XP, Xin L, Pan J, Wang D, Ji JT, Du TT, Lin $\mathrm{JH}$, Ye B. Risk Factors and Nomogram for Common Bile Duct Stricture in Chronic Pancreatitis. Journal of clinical gastroenterology. 2019 Mar 1;53(3):e91-100. 
17. Izbicki JR, Bloechle C, Broering DC, Knoefel WT, Kuechler T, Broelsch CE. Extended drainage versus resection in surgery for chronic pancreatitis: a prospectiverandomizedtrialcomparingthelongitudinalpancreaticojejunostomy combined with local pancreatichead excision with thepylorus-preserving pancreatoduodenectomy. Annals of surgery. 1998 Dec;228(6):771.

18. Izbicki JR, Bloechle C, Knoefel WT, Kuechler T, Binmoeller KF, Broelsch $\mathrm{CE}$. Duodenum-preserving resection of the head of the pancreas in chronic pancreatitis. A prospective, randomized trial. Annals of surgery. 1995 Apr;221(4):350.

19. Luaces-Regueira M, Iglesias-García J, Lindkvist B, Castiñeira-Alvariño M, Nieto-García L, Lariño-Noia J, Domínguez-Muñoz JE. Smoking as a risk factor for complications in chronic pancreatitis. Pancreas. 2014 Mar 1;43(2):275-80.

20. Negi S, Singh A, Chaudhary A. Pain relief after Frey's procedure for chronic pancreatitis. British Journal of Surgery. 2010 Jul;97(7):1087-95.

21. Pessaux $P$, Kianmanesh $R$, Regimbeau JM, Sastre $B$, Delcenserie $R$ Sielezneff I, Arnaud JP, Sauvanet A. Frey procedure in the treatment of chronic pancreatitis:short-term results. Pancreas.2006Nov 1;33(4):354-8.

22. Rajesh G, Girish BN, PanickerS, Balakrishnan V. Timetrends in the etiology of chronic pancreatitis in South India. Tropical Gastroenterology. 2015 May 1;35(3):164-7.

23. Srivastava S, Bhatia MS. Quality of life as an outcome measure in the treatment of alcohol dependence. Ind Psychiatry J. 2013;22(1):41-46. doi:10.4103/0972-6748.123617
24. Strate T, Bachmann K, Busch P, Mann O, Schneider C, Bruhn JP, Yekebas $\mathrm{E}$, Kuechler T, Bloechle C, Izbicki JR. Resection vs drainage in treatment of chronicpancreatitis:long-termresultsofarandomizedtrial.Gastroenterology. 2008 May 31;134(5):1406-11.

25. Strate T, Taherpour Z, Bloechle C, Mann O, Bruhn JP, Schneider C Kuechler T, Yekebas E, Izbicki JR. Long-term follow-up of a randomized trial comparing the Beger and Frey procedures for patients suffering from chronic pancreatitis. Annals of surgery. 2005 Apr 1;241(4):591-8.

26. Wente MN, Bassi C, Dervenis C, Fingerhut A, Gouma DJ, Izbicki JR, Neoptolemos JP, Padbury RT, Sarr MG, Traverso LW, Yeo CJ. Delayed gastric emptying (DGE) after pancreatic surgery: a suggested definition by the International Study Group of Pancreatic Surgery (ISGPS). Surgery. 2007 Nov 30;142(5):761-8

27. Wente MN, Veit JA, Bassi C, Dervenis C, Fingerhut A, Gouma DJ, Izbicki JR, Neoptolemos JP, Padbury RT, Sarr MG, Yeo CJ. Postpancreatectomy hemorrhage (PPH)- an international study group of pancreatic surgery (ISGPS) definition. Surgery. 2007 Jul 31;142(1):20-5.

28. Whitcomb DC. Genetics of alcoholic and non-alcoholic pancreatitis. Current opinion in gastroenterology. 2012 Sep;28(5).

29. Yadav D, Slivka A, Sherman S, Hawes RH, Anderson MA, Burton FR, Brand RE, LewisMD, GardnerTB, GelrudA, DiSarioJ.Smoking isunderrecognized as a risk factor for chronic pancreatitis. Pancreatology. 2010;10(6):713-9.

30. Zuidema PJ. Cirrhosis and disseminated calcification of the pancreas in patients with malnutrition. Tropical and geographical medicine. 1959;11(1):70-4. 